\title{
PERANCANGAN PROGRAM APRESIASI DAN PENGHARGAAN BAGI PEGAWAI PT.X BERBASIS WEB PADA HRMS DENGAN METODE WATERFALL
}

\author{
Wivadario Wilana ${ }^{1}$, Hanna Prillysca Chernovita ${ }^{2}$, Penidas Tanaem ${ }^{3}$ \\ 1,2,3 Fakultas Teknologi Informasi, Universitas Kristen Satya Wacana
}

\section{Article Info:}

Dikirim: 27 Juni 2019

Direvisi: 02 Agustus 2019

Diterima: 06 Agustus 2019

Tersedia Online: 31 Desember 2019

\section{Penulis Korespondensi:}

Wivadario Wilana

Universitas Kristen Satya Wacana,

Salatiga, Indonesia

Email:wivawilana@gmail.com

\begin{abstract}
Abstrak: Apresiasi dan penghargaan karyawan merupakan faktor penting di dalam perusahaan, dikarenakan karyawan akan memiliki rasa bangga dan memberikan dedikasi penuh terhadap perusahaan. Human Resource Department pada PT. X memiliki banyak sekali modul-modul besar yang dapat dikelola menggunakan program, tetapi apresiasi dan penghargaan terhadap karyawan belum dapat dikelola secara program. Tujuan dari penelitian ini adalah mempermudah pencatatan apresiasi dan penghargaan karyawan pada PT.X dengan mengubah metode dokumentasi menggunakan Microsoft Excel dengan sebuah program. Perancangan program dilakukan dengan metode perancangan dengan model Unified Modelling Language (UML) dan metode pengembangan yang digunakan adalah metode waterfall yang terdiri dari analisis, rancangan, implementasi dan pengujian terhadap program. Hasil dari penelitian memenuhi kekurangan yang selama ini PT. X butuhkan dalam mencatat apresiasi dan penghargaan karyawan secara terstruktur dan sistematis.
\end{abstract}

Kata kunci: apresiasi; UML; waterfall.

\begin{abstract}
Employee's appreciation and reward is one of many factor that is important in a company, because the employee will have a pride and giving full dedication for the company. Human Resource Department in PT.X has many big modules that could be maintained by a program, but appreciation and reward for employee has not been maintained by a program. The purpose of this research is to make PT.X's records are easier to be recored by changing its documentation way from using Microsoft Excel to a systematic and structured program. The model of this program's planning will use the Unified Modelling Language (UML) model and Waterfall Method for the development method that are based on analysis, plans, implementation and testing for the program. Results from the research could fulfill the gap that PT.X needs to record and maintain employee's appreciation and reward.
\end{abstract}

Keywords: appreciation; UML; waterfall. 


\section{PENDAHULUAN}

Perkembangan teknologi yang sangat cepat memberikan dampak kemudahan, kecepatan dan efisiensi dalam pengolahan data ataupun informasi. Tidak hanya secara individu, kelompok atau perusahaan sudah memanfaatkan teknologi setiap harinya, sehingga seluruh aktivitas dapat dilakukan lebih mudah dan cepat. Program web sangat digunakan pada era sekarang untuk memudahkan pengguna ataupun admin dalam mengolah data dan informasi, sehingga diperlukan sebuah perancangan untuk menentukan baik atau tidaknya program yang akan diimplementasi pada sebuah perusahaan.

PT.X sudah menggunakan teknologi dalam kegiatan operasionalnya. Dengan jumlah karyawan yang banyak, PT.X menggunakan sebuah sistem informasi Human Resources Management System (HRMS) untuk mengelola seluruh karyawan yang bekerja di PT.X. HRMS merupakan sebuah sistem informasi yang menjadi pusat semua aktivitas yang dibutuhkan Human Resource Department (HRD) dalam melakukan pekerjaannya, seperti mengelola data karyawan penggajian, absensi, dan lain-lain. Di dalam HRMS terdapat menu-menu utama yang menjadi pusat proses bisnis HRD, tetapi bagian apresiasi karyawan belum diimplementasikan di dalam HRMS PT.X. Apresiasi karyawan dibutuhkan untuk memberikan rasa hormat dan apresiasi terhadap karyawan PT.X yang memiliki integritas dan ketulusan dalam tindakannya, sehingga perlu dibuat Program Apresiasi dan Penghargaan Karyawan pada PT.X. Sehingga karyawan pada PT.X dapat memiliki rasa bangga terhadap dedikasinya dan juga menumbuhkan karakter-karakter positif bagi karyawan di PT.X.

Penghargaan berpengaruh positif secara signifikan terhadap kinerja karyawan(1). Apresiasi karyawan dibutuhkan untuk memberikan rasa hormat dan apresiasi terhadap karyawan PT.X yang memiliki integritas dan ketulusan dalam tindakannya, sehingga perlu dibuat Program Apresiasi dan Penghargaan Karyawan pada PT.X. Sehingga karyawan pada PT.X dapat memiliki rasa bangga terhadap dedikasinya dan juga menumbuhkan karakter-karakter positif bagi karyawan di PT.X.

Aplikasi adalah program siap pakai atau program yang direka untuk melaksanakan suatu fungsi bagi pengguna atau aplikasi yang lain(2). Aplikasi juga dapat diartikan sebuah konsep atau sistem komputer yang dibuat untuk memudahkan manusia. Website adalah suatu kumpulan halaman yang menampilkan dan berisi berbagai informasi teks, data, gambar diam ataupun bergerak, data animasi, suara, video maupun gabungan dari semuanya, baik itu yang bersifat statis maupun yang dinamis, dimana semua itu membentuk satu rangkaian bangunan yang saling berkaitan dan masing-masing dihubungkan dengan jaringan halaman atau hyperlink. Aplikasi Berbasis Web adalah sebuah aplikasi yang dapat diakses melalui internet atau intranet(3).

Permasalahan yang terjadi saat ini adalah tidak adanya sebuah program yang mengelola dan memberikan penghargaan terhadap karyawan PT.X yang melakukan perbuatan baik dan membuat citra perusahaan menjadi lebih baik. Sehingga setiap apresiasi karyawan hanya dicatat melalui dokumentasi fisik dan tidak dapat dilakukan tindakan monitoring atau pengawasan karena tidak adanya wadah untuk menyimpan informasi secara terstruktur. Sehingga perlu dirancang sebuah program Apresiasi dan Penghargaan untuk mengelola dan memantau aktivitas pengusulan apresiasi dan pemberian penghargaan terhadap karyawan yang layak mendapatkannya.

Pengembangan program dilakukan dengan menggunakan model yang bervariasi, salah satunya adalah dengan menggunakan Unified Modelling Language (UML). Penggunaan model UML memudahkan perancangan program karena mudah dipahami dan mencakup seluruh alur proses aktivitas program. Diagram yang digunakan adalah Use Case Diagram, Activity Diagram dan Class Diagram. Aktivitas yang dirancang melalui UML akan mencakup proses input sampai output. Perancangan sistem dengan menggunakan metode pemodelan UML diharapkan dapat memberikan hasil yang positif dalam perancangan terkait dengan fungsi dan proses program.

\subsection{Unified Modelling Language}

$U M L$ adalah metode pemodelan dalam mengembangkan sistem berorientasi objek dan juga merupakan metode yang digunakan mendukung pengembangan sistem(4). Diagram yang digunakan dalam $U M L$ pada perancangan sistem adalah sebagai berikut :

\subsubsection{Use Case Diagram}

Use Case Diagram adalah kegiatan atau interaksi yang saling berkesinambungan antara aktor dan sistem. Use Case Diagram merelasikan hubungan antara aktor dengan proses yang dirancang.

\subsubsection{Activity Diagram}

Activity diagram memberikan penjelasan mengenai alur dan proses yang terjadi di dalam sistem yang sedang dirancang, bagaimana semua alur berawal, kondisi yang dimungkinkan terjadi, dan bagaimana proses berakhir. Activity diagram dapat menggambarkan proses yang dapat terjadi secara berkesinambungan pada beberapa kondisi. 


\subsubsection{Class Diagram}

Class diagram menggambarkan struktur dan deskripsi class, package, objek dan hubungan antara sesama class (5). Class diagram dapat membantu dalam menvisualisasi class dari sistem. Class adalah deskripsi beberapa objek dengan atribut dan relasi yang sama (6). Struktur-struktur class diagram yang dibuat harus berelasi dan tidak berdiri sendiri-sendiri.

\subsection{Motivasi}

Motivasi merupakan dorongan terhadap serangkaian proses perilaku manusia pada pencapaian tujuan(7). Sedangkan elemen yang terkandung dalam motivasi meliputi unsur membangkitkan, mengarahkan, menjaga, menunjukan intensitas, bersifat terus menerus dan adanya tujuan. Motivasi merupakan suatu proses yang menjelaskan intensitas, arah, dan ketekunan individu untuk mencapai tujuannya (8).

\section{METODOLOGI PENELITIAN}

Metode perancangan sistem yang digunakan di dalam penelitian ini adalah metode waterfall. Pengembangan waterfall adalah metode yang berjalan sesuai dengan urutan, seperti halnya air terjun yang bergerak dari atas kebawah(9). Tahap-tahap dalam metode ini adalah Requirement, Design, Implementation, Testing dan Release.

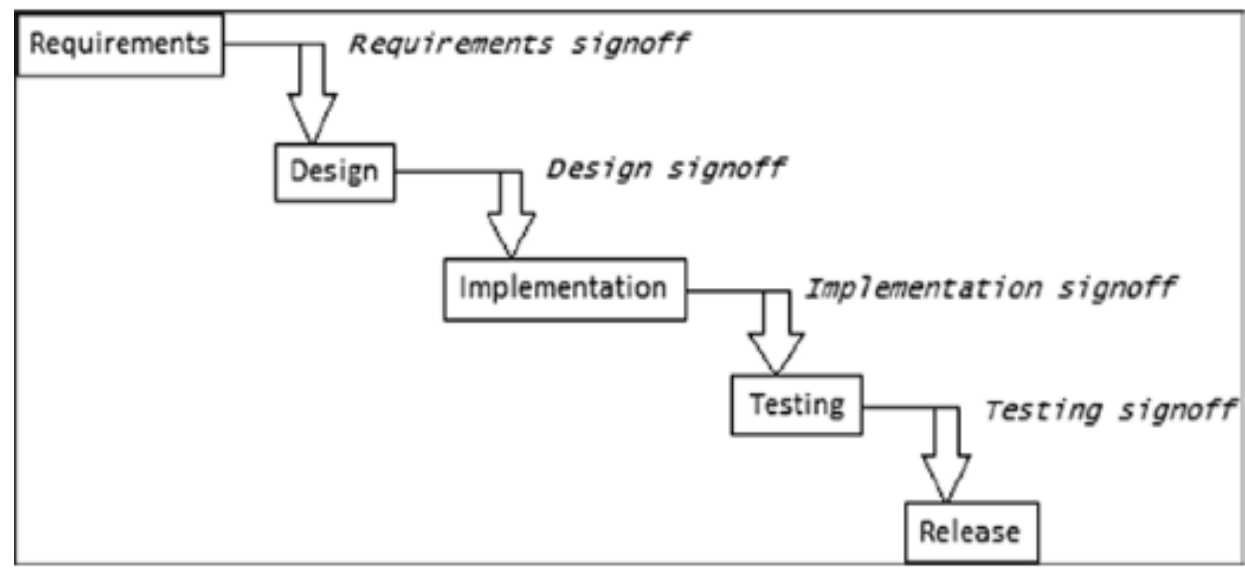

Gambar 1. Metode Perancangan Waterfall

\subsection{Requirement}

Pada tahap ini, perancangan dimulai pada analisis terhadap data yang sudah dikumpulkan. Analisis terhadap proses program dirancang mulai dari input program sampai output apa saja yang digunakan. Analisis ini diperlukan untuk memberikan hasil skema yang efisien dan efektif. Analisis resiko juga dilakukan untuk meminimalisir kesalahan hak akses terhadap program.

\subsection{Design}

Pada tahap ini, perancangan desain program dilakukan untuk memperhatikan skema perpindahan data antar proses sehingga data yang dihasilkan dapat dipertanggung jawabkan. Rancangan program disesuaikan dengan requirement user.

\subsection{Implementation}

Pada tahap ini, semua design yang telah dibuat akan diimplementasikan dalam bentuk code yang diperlukan untuk membentuk sebuah program.

\subsection{Testing}

Pada tahap ini, pengujian dilakukan untuk mencari kekurangan dan kelemahan program. Sistem diuji dengan metode Blackbox Testing. 


\subsection{Release}

Setelah program selesai di testing, program akan digunakan langsung oleh user dan dilakukan maintainance secara berkala.

\section{HASIL DAN PEMBAHASAN}

Data diolah dengan tahapan yang digunakan metode perancangan waterfall. Tahap pertama yaitu analisa kebutuhan sistem dengan meeting, dimana perancangan program disesuaikan langsung dengan user.. Tahap kedua yaitu rancangan sistem, dimana pada tahap ini, perancangan program digambarkan dengan model $U M L$. Tahap ketiga yaitu implementasi program, dimana desain tampilan dan proses di dalam program diimplementasikan ke dalam bentuk code sesuai dengan requirement user. Tahap keempat yaitu testing, dimana program yang diimplementasikan akan diuji coba dengan metode black box testing.

\subsection{Analisa Kebutuhan Sistem Dengan Meeting}

Untuk mengetahui kebutuhan dari user mengenai penghargaan karyawan, dilakukan sebuah meeting yang ditujukan untuk mendapat requirement dan juga pemecahan masalah. Melalui meeting ini, didapat berbagai macam menu dan role yang nantinya akan ada di dalam program penghargaan karyawan, yaitu:

\subsubsection{HRD Pusat}

1) Pengusulan: menu yang digunakan untuk membuat pengusulan penghargaan bagi karyawan PT.X. Transaksi approval atau reject dilakukan di dalam menu pengusulan

2) Cetak Reward: menu yang digunakan untuk mencetak sertifikat untuk jenis pengusulan yang sudah disetujui.

3) Finish Reward: menu yang digunakan untuk menyelesaikan laporan dari pengusulan-pengusulan yang sudah disetujui pihak HRD.

4) History Reward: menu yang digunakan untuk mengakses laporan data baik yang sudah di prosses maupun yang baru dibuat.

\subsubsection{HRD Cabang}

1) Pengusulan: menu yang digunakan untuk membuat pengusulan penghargaan bagi karyawan PT.X. Transaksi approval atau reject dilakukan di dalam menu pengusulan

2) Finish Reward: menu yang digunakan untuk menyelesaikan laporan dari pengusulan-pengusulan yang sudah disetujui pihak HRD.

3) History Reward: menu yang digunakan untuk mengakses laporan data baik yang sudah di prosses maupun yang baru dibuat.

\subsection{Rancangan Sistem}

Rancangan sistem digambarkan dengan metode pemodelan UML (Unified Modelling Language). Terdapat Use Case Diagram, Activity Diagram dan Class Diagram untuk setiap prosesnya. Berikut merupakan rancangan sistem pada program apresiasi dan penghargaan karyawan: 


\subsubsection{Use Case Diagram}

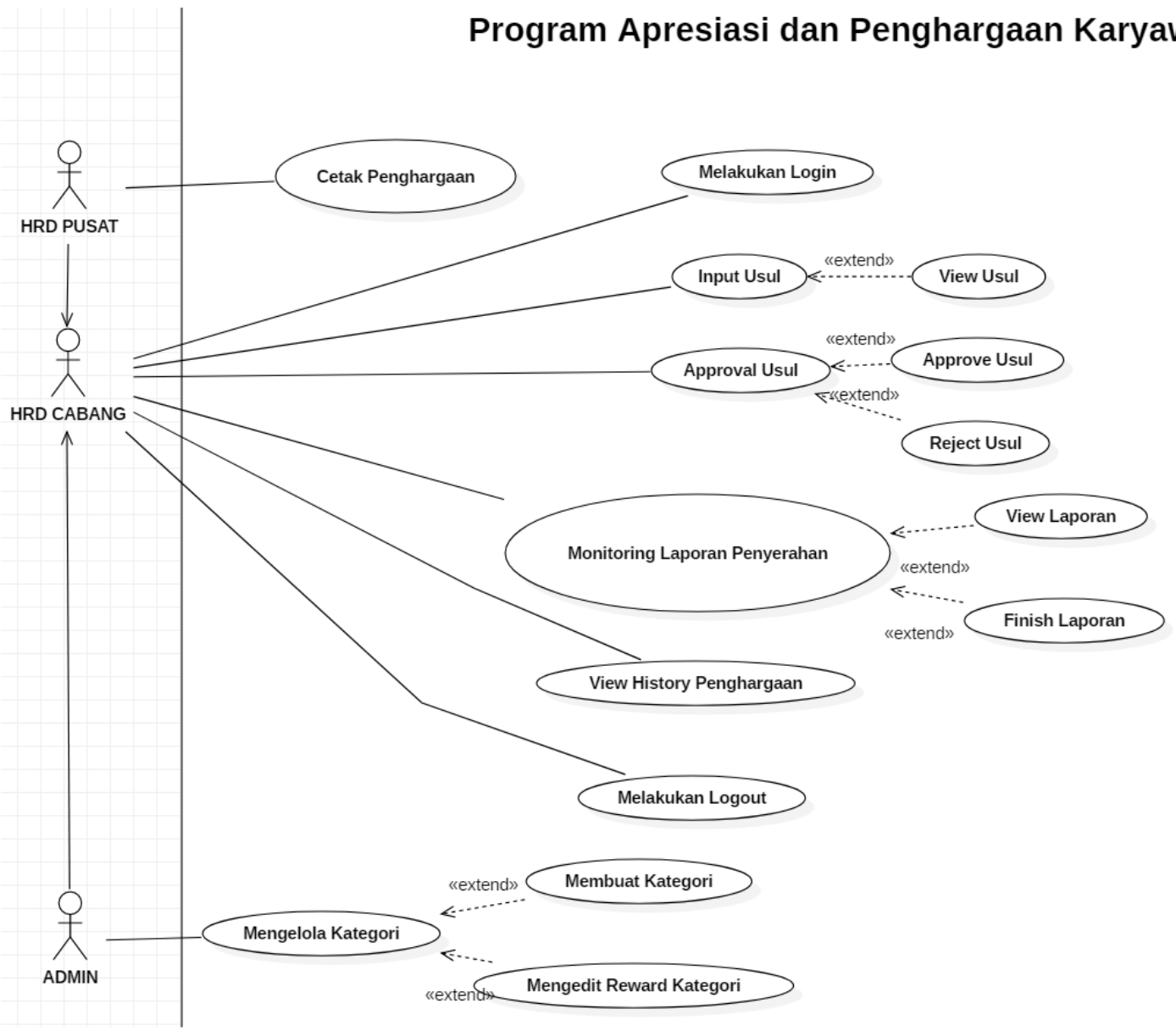

Gambar 2. Perancangan Use Case Diagram

1) Input Usul : Actor melakukan input pengusulan di dalam sistem

2) Approve Usul : Actor men-validasi dan menyetujui pengusulan yang sebelumnya sudah di-input dan disimpan oleh sistem

3) Reject Usul : Actor melakukan penolakan terhadap pengusulan yang sebelumnya sudah di-input dan disimpan oleh sistem

4) View Laporan: Actor melihat data pengusulan yang sudah disetujui

5) Cetak Penghargaan : Actor mencetak sertifikat penghargaan sesuai dengan pengusulan yang sudah disimpan oleh sistem

6) Finish Laporan : Actor melengkapi data laporan penyerahan di dalam sistem

7) View History Penghargaan : Actor melihat rekapitulasi seluruh pengusulan yang pernah di-input di dalam sistem

8) Membuat Kategori : Actor dapat membuat master data kategori

9) Mengedit Reward Kategori : Actor dapat mengubah maupun menambahkan penghargaan pada setiap kategori penghargaan 


\subsubsection{Activity Diagram}

1) Activity Diagram Input Usul

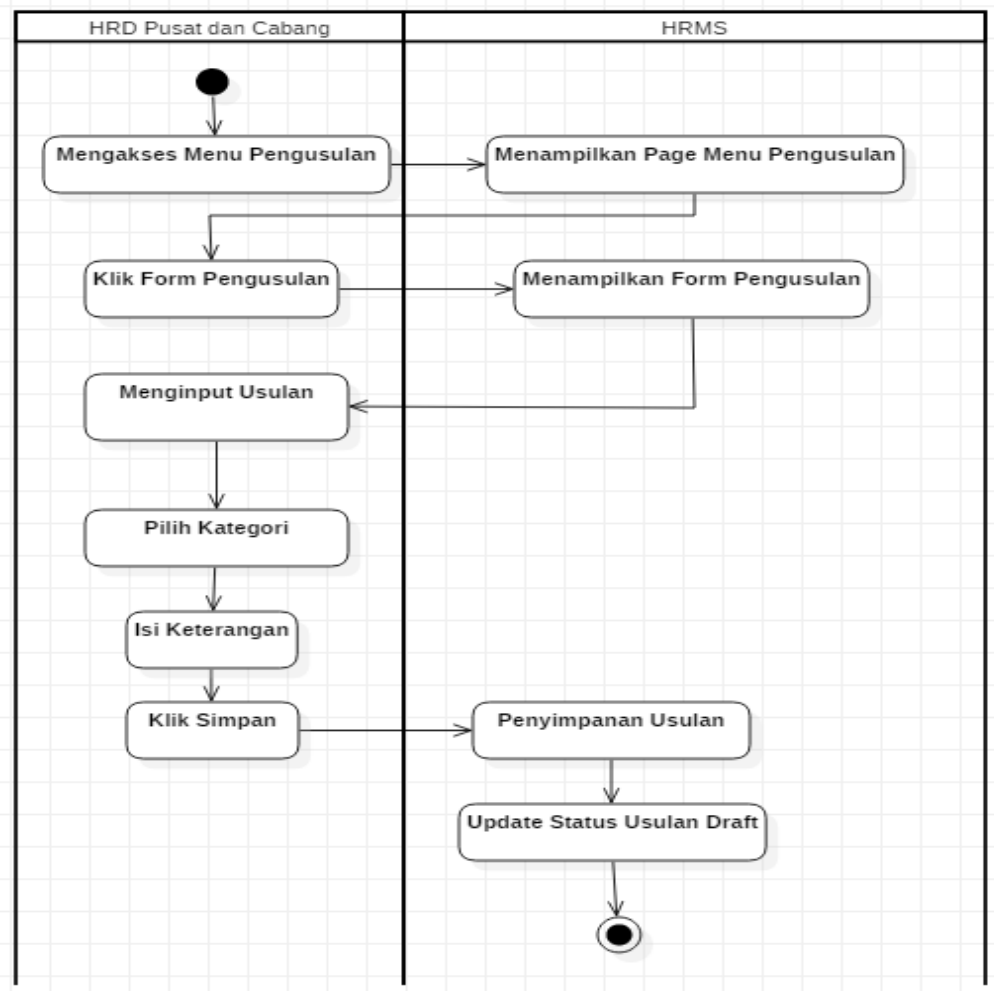

Gambar 3. Activity Diagram Input Usul

Pada gambar 3, HRD Pusat dan cabang menginput pengusulan melalui mеnu pengusulan. HRD Pusat dan cabang harus memilih kategori pengusulan dan mengisi keterangan. Menyimpan pengusulan yang sudah di-input akan mengubah status data menjadi draft.

2) Activity Diagram Approve dan Reject Usul

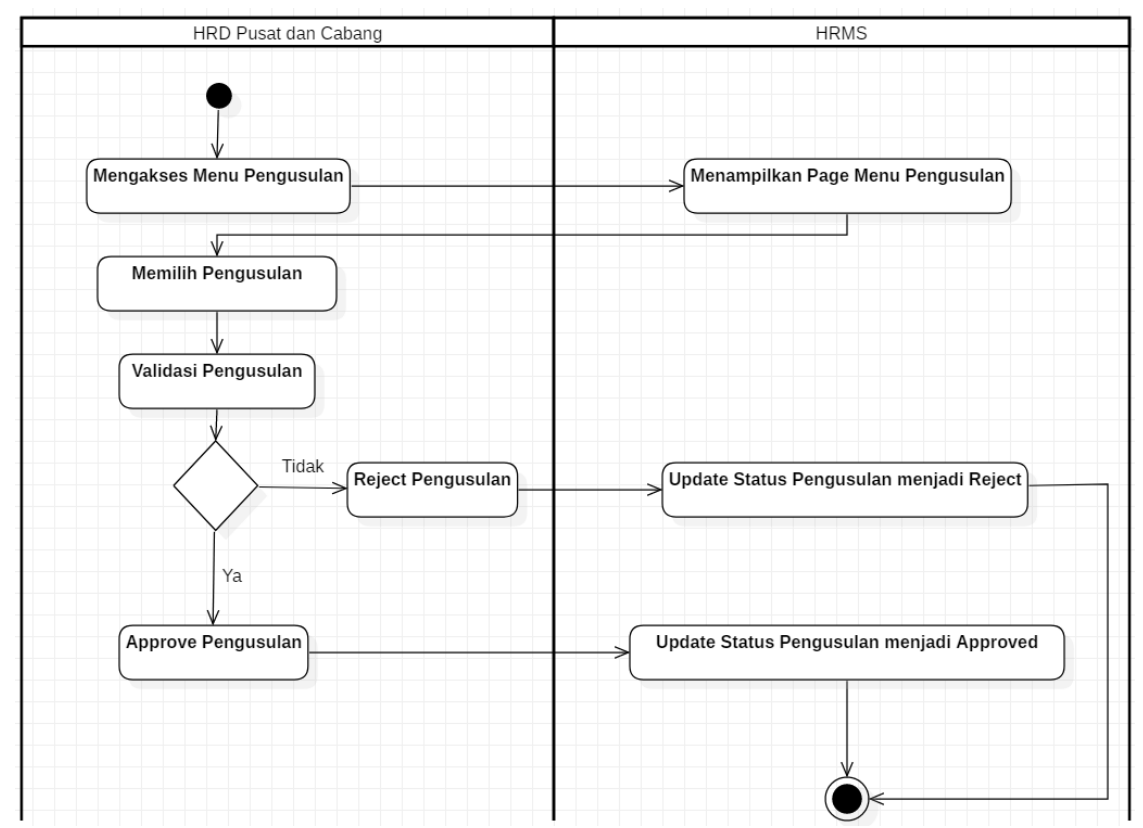

Gambar 4. Activity Diagram Approve dan Reject Usul 
Pada gambar 4, HRD Pusat dan cabang melakukan validasi terhadap data pengusulan di dalam sistem. Persetujuan pengusulan akan mengubah status data menjadi Approved. Penolakan pengusulan akan mengubah status data menjadi Reject.

\subsubsection{Class Diagram}

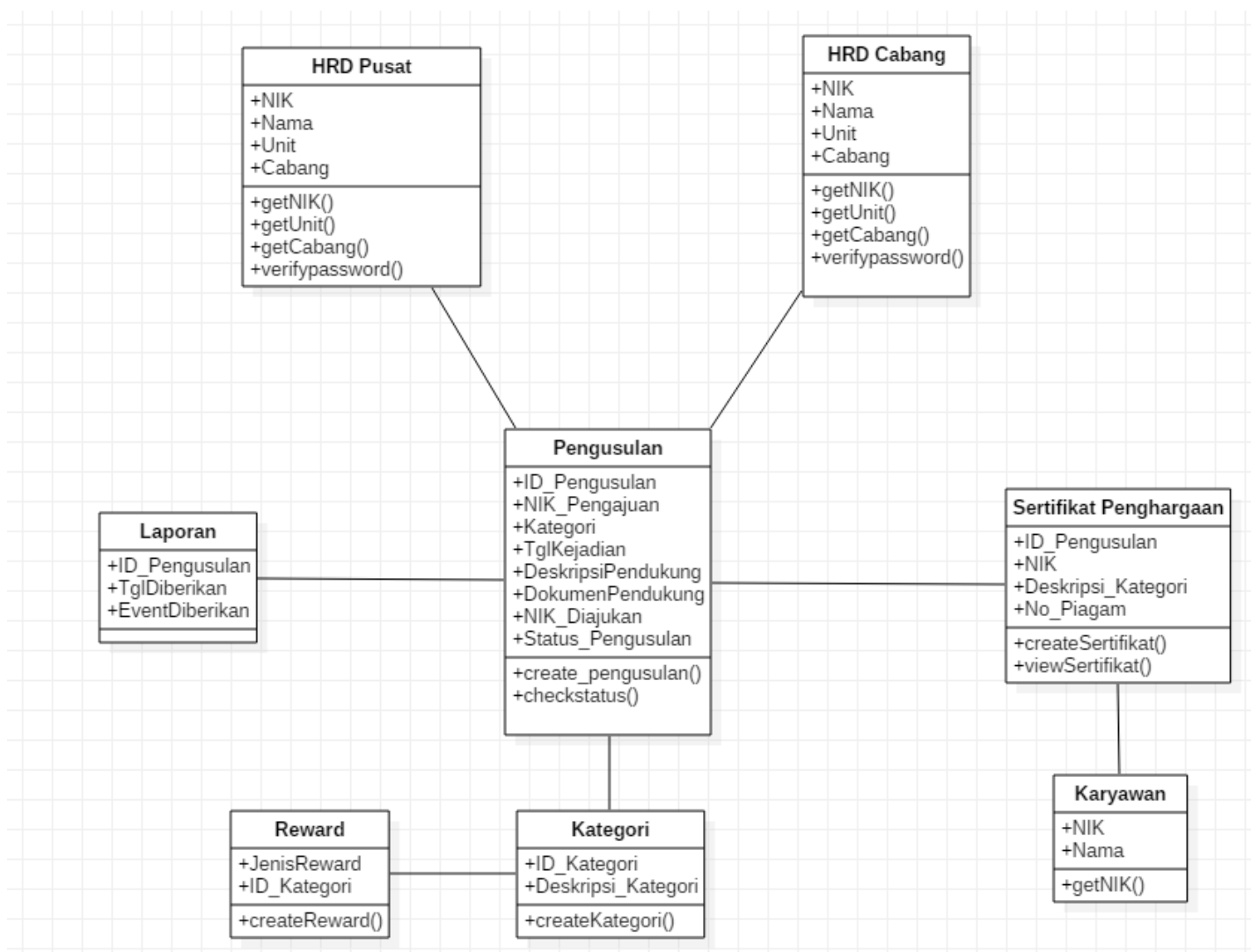

Gambar 5. Perancangan Class Diagram

1) HRD Pusat : Class HRD Pusat memiliki relasi dengan Class Pengusulan dimana satu HRD pusat dapat membuat banyak pengusulan

2) HRD Cabang : Class HRD Cabang memiliki relasi dengan Class Pengusulan dimana satu HRD cabang dapat membuat banyak pengusulan

3) Pengusulan : Class Pengusulan memiliki relasi dengan Class HRD Pusat, HRD cabang, Laporan, Sertifikat Penghargaan, dan Kategori dengan nilai kardinalitas seperti berikut ;

a. Satu atau lebih pengusulan dimiliki oleh satu HRD Pusat

b. Satu atau lebih pengusulan dimiliki oleh satu HRD Cabang

c. Satu pengusulan hanya memiliki satu laporan

d. Satu pengusulan hanya memiliki satu sertifikat penghargaan

e. Satu pengusulan hanya memiliki satu kategori

4) Karyawan: Class Karyawan memiliki relasi dengan Class Sertifikat Penghargaan dimana satu karyawan hanya memiliki satu sertifikat penghargaan

5) Reward: Class Reward memiliki relasi dengan Class Kategori dimana satu atau lebih reward memiliki satu atau lebih kategori. 


\subsection{Implementasi Program}

\subsubsection{Menu Pengusulan}

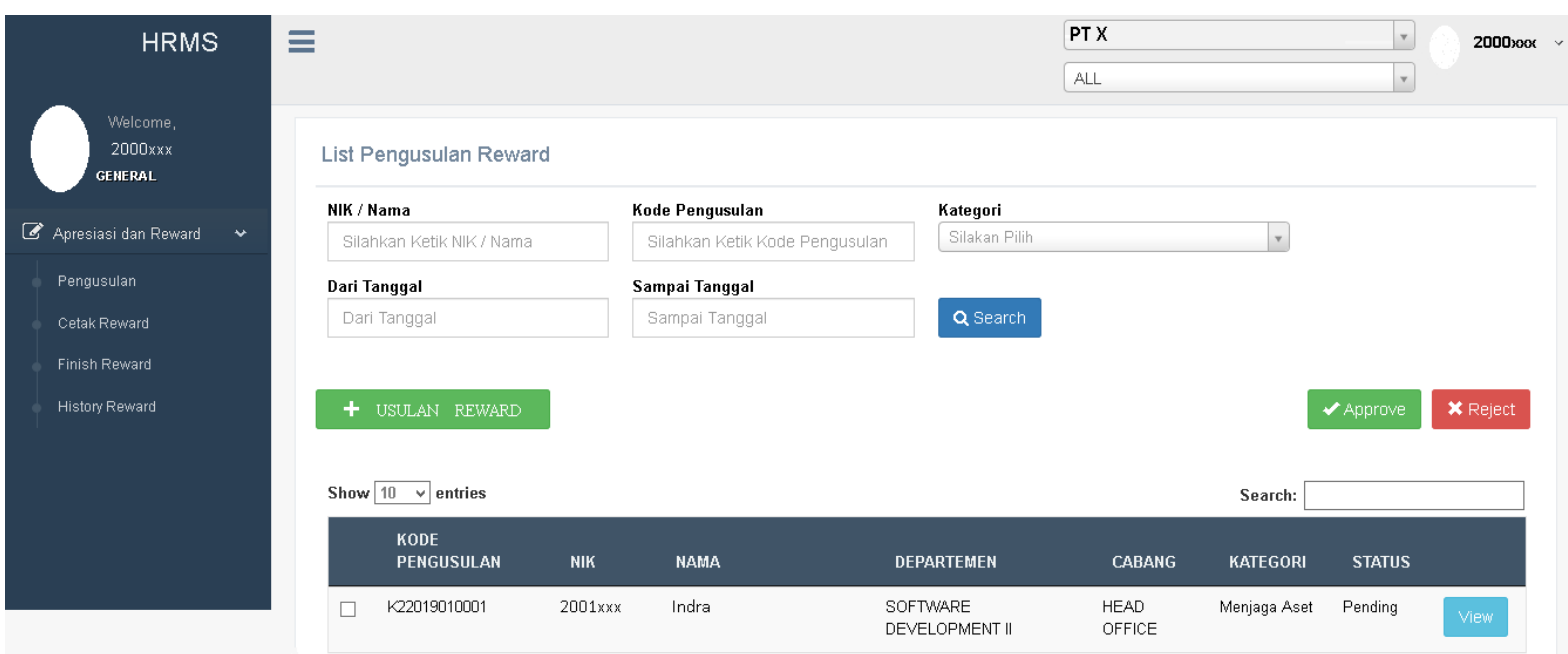

\section{Gambar 6. Menu Pengusulan}

Pada gambar 6, menu untuk membuat pengusulan. Menu ini juga menampilkan data yang sudah pernah diinput sebelumnya. Penyetujuan dan penolakan data pengusulan juga dilakukan di dalam menu ini.

\subsubsection{Form Input Pengusulan}

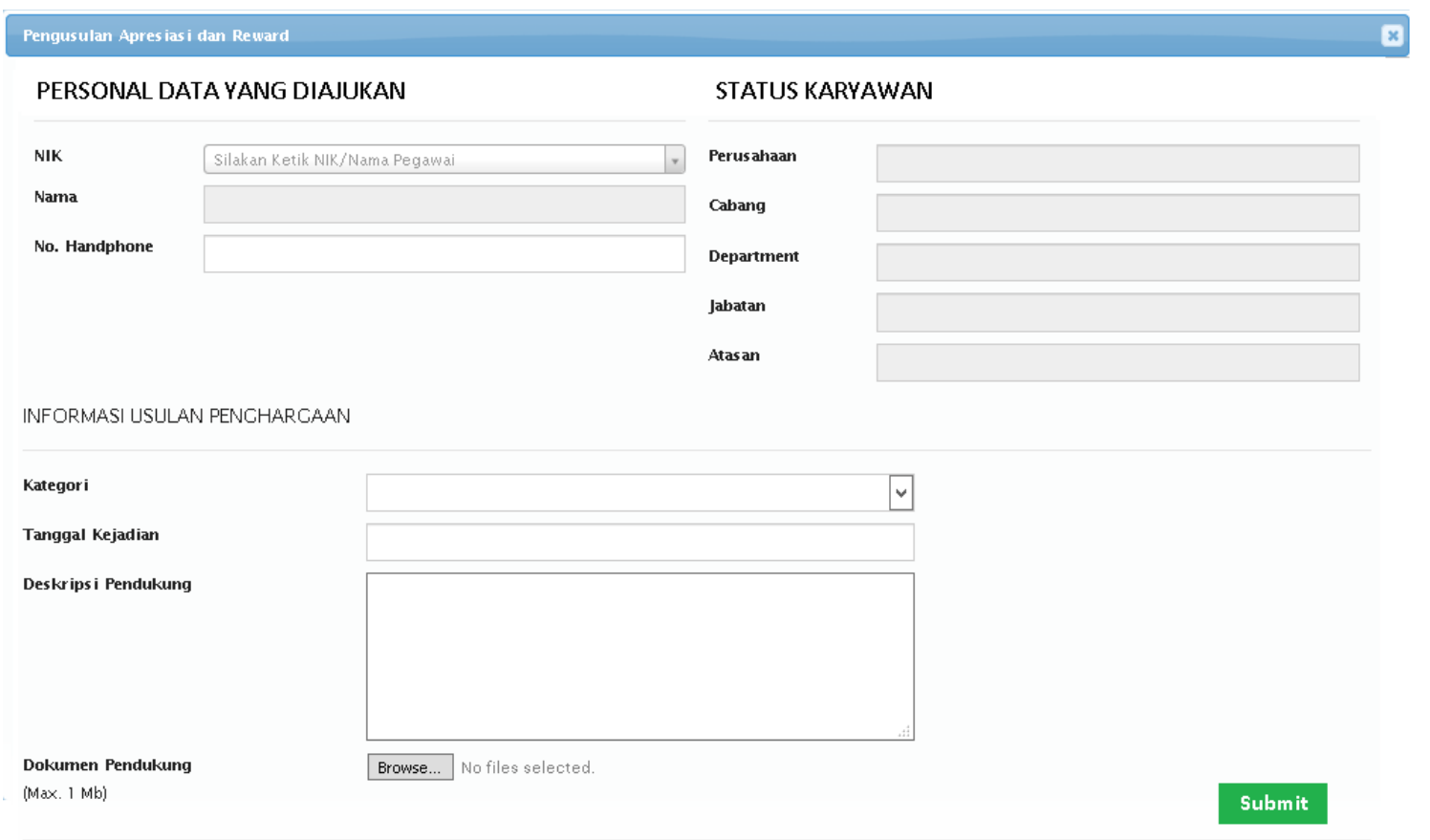

\section{Gambar 7. Form Input Pengusulan}

Pada gambar 7, Form Pengusulan diisi oleh user. User harus mengisi semua data untuk melengkapi form pengusulan sebelum data disimpan. 


\subsubsection{View Pengusulan}

Pengusulan Apresiasi dan Reward

PERSONAL DATA YANG DIAJUKAN

NIK

Nama

No. Handphone

$2000 \times x \times x x$

$\mathrm{ABC}$

$08 \times x \times x \times$
STATUS KARYAWAN

Perusahaan

Cabang

Department

Jabatan

Atasan

\begin{tabular}{|l|}
\hline PT. $X$ \\
\hline Jakarta \\
\hline IT Development \\
\hline Junior Manager \\
\hline XYZ \\
\hline
\end{tabular}

INFORMASI USULAN PENCHARCAAN

Kategori

Tanggal Kejadian

Deskripsi Pendukung

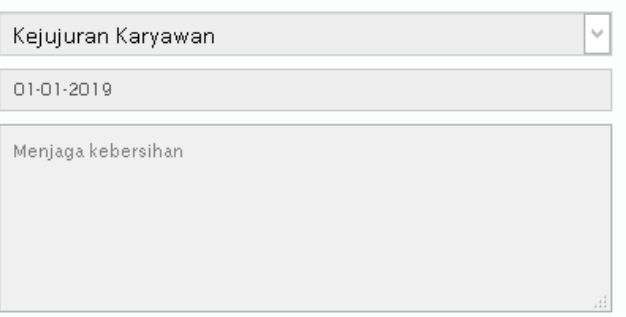

\section{Gambar 8. Form View Pengusulan}

Pada gambar 8, Data pengusulan yang sudah disimpan dapat dilihat di dalam program dalam bentuk form seperti berikut. Form ini hanya dapat dilihat oleh user.

\subsubsection{Menu Cetak Reward}

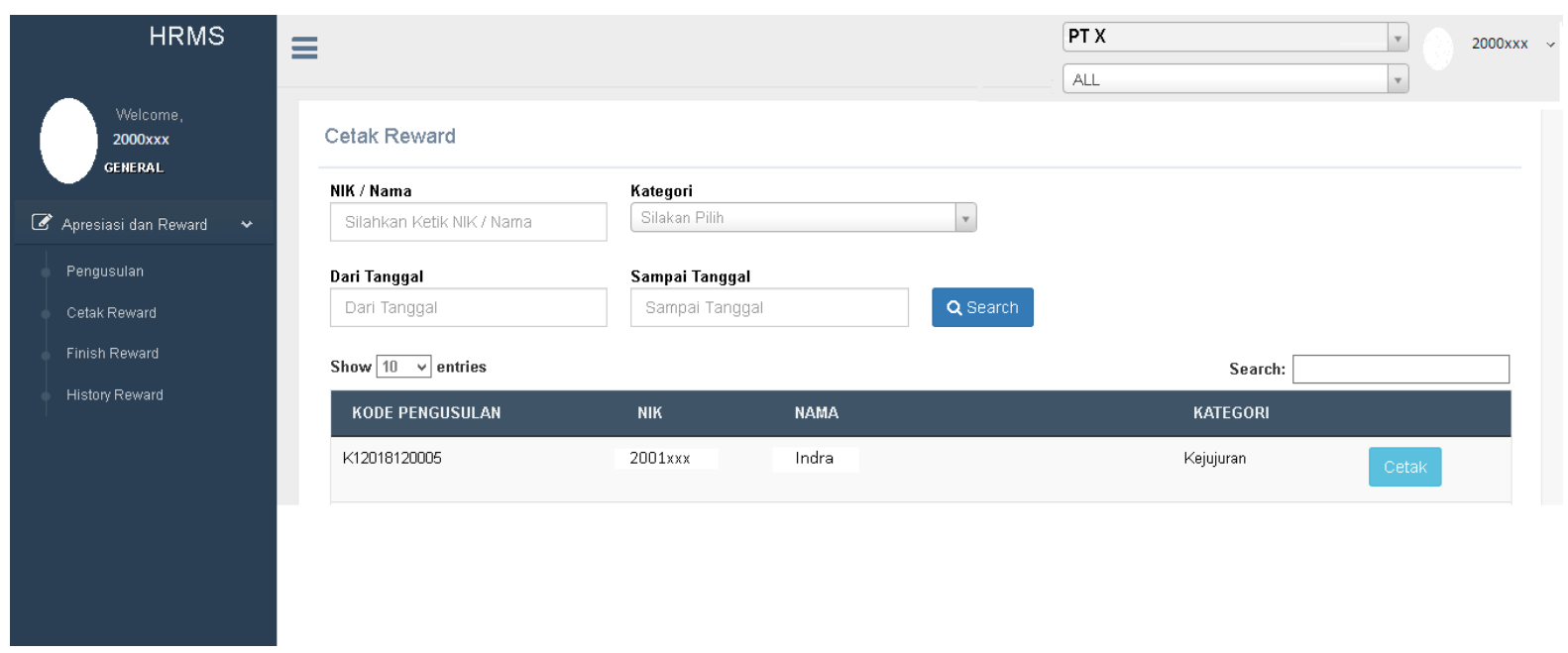

\section{Gambar 9. Menu Cetak Reward}

Pada gambar 9, Menu ini digunakan untuk mencetak sertifikat penghargaan pada data pengusulan yang sudah disetujui dan divalidasi. Data dengan status Approved dapat dicetak pada menu cetak reward. 


\subsubsection{Menu Finish Reward}
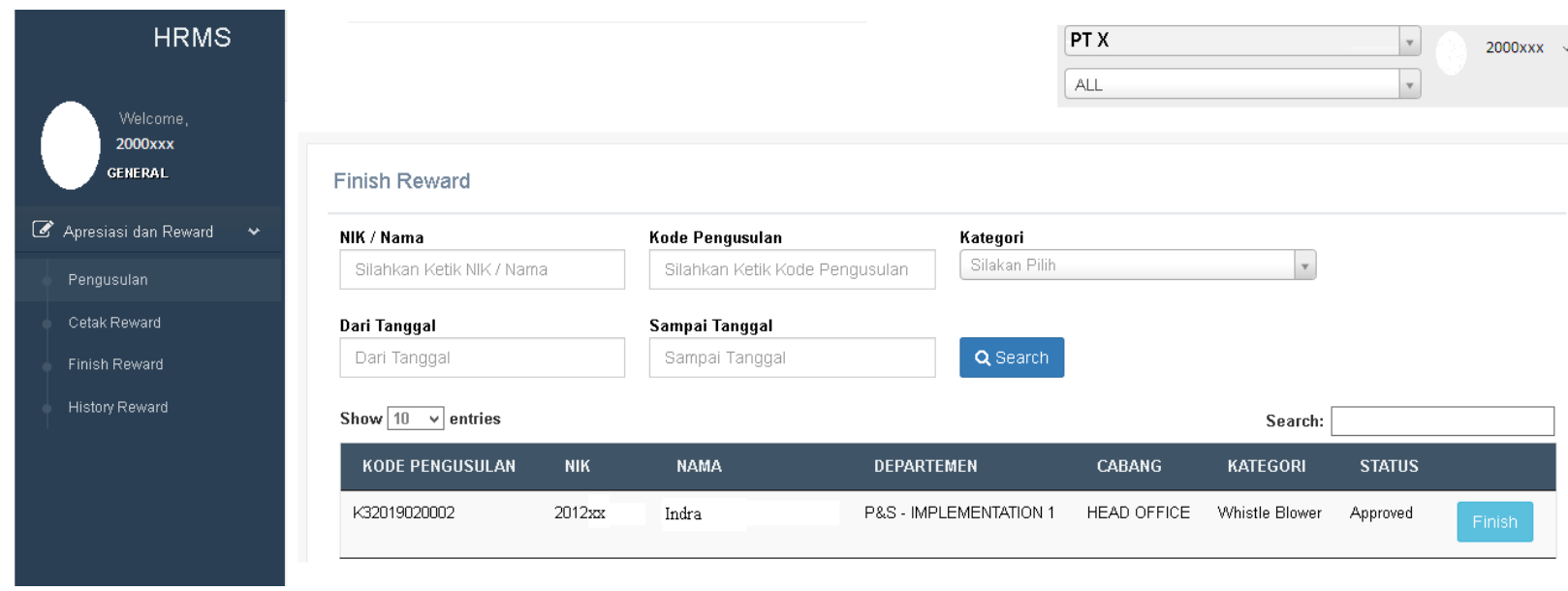

Gambar 10. Menu Finish Reward

Pada gambar 10, Menu ini digunakan untuk menyelesaikan laporan pengusulan pada data pengusulan dengan status Approved. Data dengan status Approved selalu muncul pada menu ini.

\subsubsection{Menu History Reward}
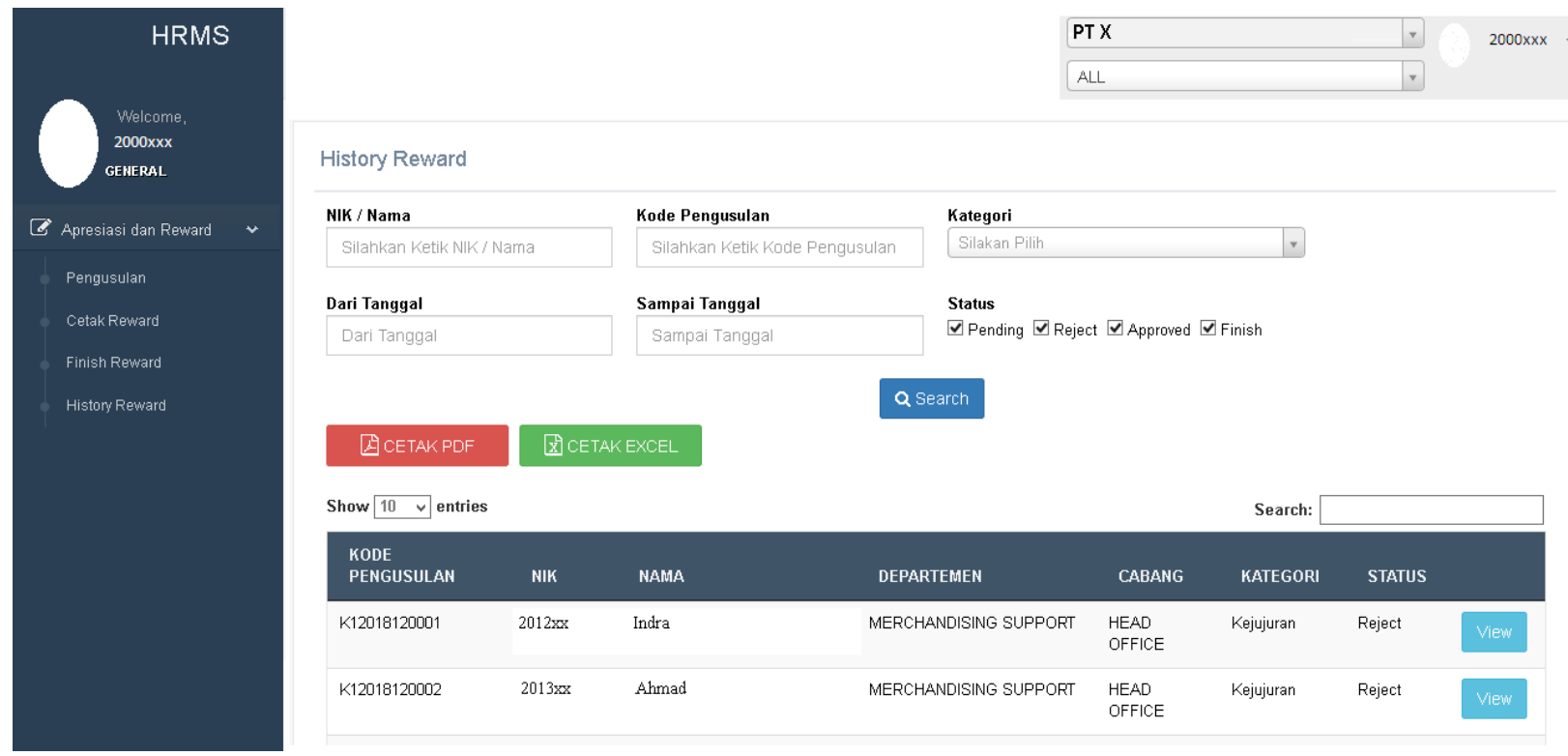

Gambar 11. Menu History Reward

Pada gambar 11, Menu ini digunakan untuk melakukan rekapitulasi data pengusulan yang sudah di-input maupun sudah selesai. User dapat melakukan filtering pada pencarian data sehingga performa program dapat bekerja secara maksimal.

\subsection{Testing}

Program yang sudah diimplementasikan di uji coba dengan metode pengujian black box testing. Pengujian dilakukan untuk menemukan kegagalan proses pada program. Berikut merupakan hasil dari testing yang dilakukan dengan metode black box testing. 
Tabel 1. Hasil black box testing

\begin{tabular}{|c|c|c|c|}
\hline No & Action & Hasil yang diharapkan & Hasil \\
\hline 1 & Input Usul & $\begin{array}{l}\text { Dapat menginput pengusulan ke } \\
\text { dalam program }\end{array}$ & Sesuai \\
\hline 2 & Approve Usul & $\begin{array}{l}\text { Dapat menyetujui dan melakukan } \\
\text { validasi data pengusulan di dalam } \\
\text { program }\end{array}$ & Sesuai \\
\hline 3 & Reject Usul & $\begin{array}{c}\text { Dapat melakukan penolakan } \\
\text { terhadap data pengusulan di dalam } \\
\text { program }\end{array}$ & Sesuai \\
\hline 4 & View Usul & $\begin{array}{l}\text { Dapat melihat isi pengusulan yang } \\
\text { sudah di-input di dalam program }\end{array}$ & Sesuai \\
\hline 5 & Cetak Sertifikat & $\begin{array}{c}\text { Dapat mencetak sertifikat } \\
\text { penghargaan pada pengusulan } \\
\text { yang sudah disetujui dan } \\
\text { divalidasi di dalam program }\end{array}$ & Sesuai \\
\hline 6 & Finish Laporan & $\begin{array}{c}\text { Dapat melakukan finalisasi } \\
\text { terhadap pengusulan yang akan } \\
\text { diberikan kepada karyawan di } \\
\text { dalam program, seperti tanggal } \\
\text { penyerahan, hadiah dan acara } \\
\text { penyerahan }\end{array}$ & Sesuai \\
\hline 7 & View History Reward & $\begin{array}{l}\text { Dapat melihat rekapitulasi seluruh } \\
\text { data pengusulan yang sudah } \\
\text { pernah di-input kedalam program }\end{array}$ & Sesuai \\
\hline
\end{tabular}

Hasil testing menunjukkan bahwa tidak ada kegagalan proses di dalam setiap menu pada program. Setiap proses berjalan sesuai dengan perancangan yang sudah disesuikan dengan user, sehingga program sudah siap digunakan oleh user.

\section{KESIMPULAN}

Berdasarkan dari penelitian yang sudah dilakukan, penerapan metode waterfall pada program apresiasi dan penghargaan karyawan pada PT. X akan berjalan dengan baik. Berikut merupakan kesimpulan terhadap penelitian ini:

1) Melalui meeting yang dilakukan dengan user, kebutuhan dan spesifikasi program dapat disesuaikan secara optimal sehingga program dapat dirancang dan dibuat dengan benar dan baik

2) Program Apresiasi dan Penghargaan bagi Karyawan PT. X dapat digunakan untuk memberikan penghargaan terhadap karyawan yang melakukan perbuatan yang baik dan mulia untuk Perusahaan PT. X

3) Dengan adanya program ini, seluruh aktifitas dokumentasi dapat dicatat di dalam program sehingga seluruh proses dapat diawasi dengan detil dan benar

4) Testing yang dilakukan memberikan pemahaman secara mendalam kepada user terhadap program yang akan digunakan, sehingga user tidak gagal paham dalam menggunakan program.

\section{DAFTAR PUSTAKA}

[1] Prabu A, Wijayanti D. Pengaruh Penghargaan dan Motivasi Terhadap Kinerja Karyawan ( Studi Pada Divisi Penjualan PT. United Motors Center Suzuki Ahmad Yani , Surabaya ). J Ekon Bisnis dan Kewirausahaan. 2016;5(2):104-17.

[2] Nugraha U, Pardiniasa M. ANALISIS SISTEM INFORMASI PEMASARAN PRODUK BERBASIS WEB DENGAN PEMODELAN UML. Pros Semin Ilmu Komput dan Teknol Inf. 2017;2(1):2540-2.

[3] Simarmata J. Rekayasa Perangkat Lunak. Yogyakarta: Penerbit Andi; 2010.

[4] Urva G, Siregar H. Pemodelan UML E-Marketing Minyak Goreng. J Teknol dan Sist Inf. 2015;1(9):92101.

[5] Novianta MA, Setyaningsih E. Sistem Informasi Monitoring Kereta Api Berbasis Web Server Menggunakan layanan GPRS. Momentum. 2015;17(2):58-67.

[6] Hayat A, Prastica T, Susanti, Isyamarwati A. Prototipe Sistem Informasi Persediaan Barang Logistik Berbasis Web Dengan Pemodelan UML. Konf Nas Sist Inform [Internet]. 2015;2(Sistem Informasi):9-10. Available from: http://ejournal.stikom-bali.ac.id/index.php/knsi/article/view/503 
Jurnal SITECH, Vol 2, No 2, Desember 2019

$P-I S S N$ : 2615-8531, E-ISSN : 2622-2973

[7] Wibowo. Manajemen Kinerja. Jakarta: PT.Rajagrafindo Persada; 2014.

[8] Effendi U. Asas Manajemen. Jakarta: PT.Rajagrafindo Persada; 2015.

[9] Crookshanks E. Practical Software Development Techniques: Tools and Techniques for Building Enterprise Software. New York: Apress Publisher; 2014. 